Chapter 22

\title{
Locating a sense of immortality in early Egyptian cemeteries
}

\author{
Alice Stevenson
}

\section{Introduction}

It has often been remarked, and rightly, that there is a close relationship between the representation of the body and that of the soul. This mental connection is necessary, not only because collective thought is primarily concrete and incapable of conceiving a purely spiritual existence, but above all because it has a profoundly stimulating and dramatic character.

Hertz 1960: 83

Despite the passing of a century, Hertz's seminal work of 1907, Contribution à une Étude sur la Représentation Collective de la Mort, remains a source of inspiration for many modern interpretations of mortuary practices. Most such studies have taken Hertz's schema of secondary funerary rites as their primary focus, but it is his wider frame of reference with its emphasis on the communal, affective experience of mortuary rituals that is the theoretical stance explored further here. Notably in this vein, his ideas have wider resonance today with the more recent anthropological emphasis on emotion and embodiment (Davies 2000, 97-8) and with studies seeking to link the spiritual and the material (Venbrux 2007). Such collective representations of death can provide particularly germane departure points for the inference of prehistoric notions of immortality. ${ }^{1}$ Instead of grappling with the thorny issue of personal belief, such representations allow the focus of analysis to be shifted to the shared, material contexts of experience and meaningmaking, which are more visible to archaeologists (Tarlow 2000; DeMarrais 2011). In pursuing this line of reasoning with reference to the early Egyptian evidence, I take a position already adopted by several other scholars (e.g. Hodder 2010; Kertzer 1988, 76; Price 2008; Rappaport 1999, 119-20) that concepts of spirituality (or in this case immortality) need not entail structured belief, but rather that in particular spaces and in particular scenarios an embodied sense of transcendental being can be created and encountered. In terms of the context of death, I take this to be commensurate with what the psychologists Lifton \& Olson (1974) referred to as 'experiential immortality', key to which is the feeling of the reorientation of time. Yet contrary to their assertion that this experiential immortality emerges because of an individual's innate sense of their own perpetuity, I contend, following recent suggestions in cognitive science (Hodge 2011a, 2011b) and in keeping with Hertz's emphasis on the social, that it emerges from people's intuitive sense of the continued existence of others. Building on these points, I suggest here that one way in which a sense of immortality can be stimulated is through the communal experience of how others are buried and how social relationships are dramatized in burial rites and settings.

In the case of early Egypt, from the late Neolithic through to early bronze age, social relationships were dramatically reconfigured over an interval of some 1500 years, from seasonally mobile pastoralist communities to a state society headed by divine kingship. It is a transformation that is most visible in the mortuary realm. Within this context an extraordinary range of behaviours is evident: $^{2}$ the establishment of the first long-term, formal cemetery areas; the rapid and diverse material elaboration of display-orientated mortuary ritual; wide-ranging experimentation in body treatments including dismemberment, secondary burial and partial mummification; theatres of human and animal sacrifice on an unprecedented scale; and, from the First Dynasty, the imposition upon the landscape of massive burial structures. The implication of this spectrum of practices is that 
we should not envisage one single trajectory of cosmological development leading neatly to conceptions of the afterlife that are so well documented from later Pharaonic texts and art. Nor should we expect there to have existed formalized or codified sets of beliefs at this early time. Instead, the evidence provides the possibility of exploring how communities negotiated their confrontation with death and the arenas that may have actively shaped collective senses of immortality and transcendence. In viewing the evidence in this way what is striking is the discontinuities in the archaeological record, rather than the continuities. The most significant of these was the establishment of divine and immortal kingship. This, I argue, was achieved not primarily through the elevation of ancestors to divine status, as is so frequently invoked, but via fundamental changes in the spatial dramatization of immediate social relationships and the concomitant reorientation of time and space as materialized in the royal cemetery of Egypt's First Dynasty at Abydos.

\section{Experiential immortality}

In the early 1970 s the psychiatrists Lifton \& Olson (1974) published a theory of symbolic immortality in order to explain how people managed their fear of death. They postulated that this found expression in five modes of what they called 'symbolic immortality': biological, creative, theological, natural and experiential immortality. Biological immortality refers to continuity through progeny, kinship and other important social groupings; creative immortality is the posterity that can be found through such activities as teaching, writing and art-making; theological immortality references the religious construction of afterlife beliefs; while natural immortality links life to wider cycles of birth and death, and perceptions of the endurance of the landscape despite the passing of generations. The final mode, experiential transcendence, is set apart from the previous four as it is predicated upon a psychological state that can occur in relation to all of the other modes. This mode of immortality refers to the feeling of being beyond the boundaries of mundane daily rhythms, of transcending time itself: "one feels oneself alive in a 'continuous present' in which ancient past and distant future are contained" (Lifton \& Olson 1974, 87). Such experiences may vary in their intensity and can be found in many different scenarios from music to sport to sexual encounters, but notably also in the contemplation of the past and in communal ceremonies. While all five of these forms of symbolic immortality are certainly documented as concerns for the ancient Egyptians of the historic period, in the absence of written records it is the final mode that is the focus in this study of early Egyptian rites.

Lifton \& Olson linked the emergence of symbolic immortality to a universal fear of death and to an individual's innate sense of his or her own perpetuity in the face of this. Recent experimental findings in the cognitive science of religion (e.g. Bering 2002; 2006; 2008) would seem support these notions, as they indicate that human beings do intuitively believe in an afterlife. The tests upon which these assertions were based demonstrated that children from the age of four were predisposed to believe that some psychological states continued on for deceased individuals. It is a trend that persists through adulthood regardless of religious affiliation. In accounting for this, there has been a tendency to focus upon an individual's sense of their own immortality, which, it is argued, is then extended to others. Following Hodge (2011a, 2011b), however, and in keeping with Hertz's emphasis on the social, it is possible to argue that a sense of immortality emerges not from people's natural propensity to imagine their own survival after death, but from people's intuitive sense of the continued existence of others: 'the thesis that afterlife beliefs are social in nature... suggests that afterlife beliefs are other-centered and not self-centered' (Hodge 2011a, 404). This, Hodge proposes, is a product of 'off-line social reasoning', a well-documented imaginative process that allows humans to conceptualize and plan interactions with absent third parties: 
When it comes to death, human cognition apparently is not well equipped to update the list of players in our complex social rosters by accommodating the recent nonexistence of any one of them. This is especially the case, of course, for individuals who have played primary roles in our social lives, who did so for a long time, and who were never presumed to be continuously stationary when they were out of our sight... although these automatic cognitions are probably the residue of habitual social behaviors, they also reveal something about the challenges faced by the human cognitive system when it attempts to process information concerning the truth about dead agents' physical whereabouts. A person who has recently died and whose body has already been disposed of may continue to be processed by an offline social system for an undetermined period of time (Bering 2006, cited in Hodge 2011a, 404).

This uniquely human capacity is what allows us to engage with what Bloch refers to as the 'transcendental social' (Bloch 2008; Hodder 2010, 334)-how people can conceptualize the continuation of social roles beyond the life of an individual. It allows us to imagine how social structures can endure. As the supreme example of 'total social phenomena' (Mauss 1967, 77-8), mortuary rituals provide the cultural setting within which an embodied encounter with this transcendental social can occur, when communities are no longer simply imagined (Anderson 1983), but become, for perhaps just a fleeting moment, perceptible. How others are buried and how social relationships are enacted-especially if done a dramatic and stimulating fashion-are two of the ways in which an embodied sense of immortality may be instantiated.

Commented [AS1]: Hope this works a little better?

Archaeologically, such observations are significant for it suggests that it may be possible to interarticulate the analysis of social organization - which has long been seen as the primary determinant of variation in mortuary practices and subject to extensive archaeological analysis-with the consideration of cosmologies and spirituality-which has received considerably less systematic attention (Carr 1995). In accounts that have sought to address what Carr termed 'philosophicalreligious' aspects of the mortuary record, the focus has largely been on how religious constructs determine patterns of behaviour. Models such as this align with a long intellectual lineage of constructivist perspectives that have viewed symbols and rituals as a means of projecting preexisting cultural and social codes onto the material world (Boivin 2009). Such approaches remain particularly problematic, however, if analysis is seeking to explain the emergence of practices or account for changes over long periods of time.

The perspective taken here reformulates Carr's view to consider how mortuary practices may not only be directed by belief, but how they may also contribute to very appearance and development. Going further, in the examination of the possible 'origins' of beliefs it is in fact not necessary to assume that rituals are prefigured by formalized or existing concepts (Boivin 2009, 274), for rituals are creative acts, not merely communicative ones (Bell 1997, 72-83). In this sense the use of the term 'performance'-which has for almost two decades been employed in archaeological investigations of ancient burials (e.g. Barrett 1994; Laneri 2007; Pearson 1998; Thomas 1999)might not be the most appropriate to use in cases such as this, suggesting as it does the repetition and enactment of pre-existing codes. Rather, we might consider Seremetakis' use of the term poesis, which she defines as 'the making of something out of that which was previously experientially and culturally unmarked' (Seremetakis 1991, 7). Poesis here is conceived of as an aesthetic act which makes sense of cultural forms at the very moment of their material and affective inception. Death creates the potential social space for such poesis, for as it punctuates daily rhythms it provides new opportunities to materialize and generate alternative realities and frameworks as individuals participate in transformative communal rituals. The settings in which some these events are played out-cemeteries-form an important part of this materialization. Significantly, they are also the contexts that are most conspicuous in our data for early Egypt. In exploring these ideas the following overview of mortuary development in the Nile Valley is necessarily selective, and I have chosen to 
focus principally on how the dead were located and framed relative to each other and the living, rather than attend to the variations in body treatments or the selection of grave goods.

\section{Early Egyptian Burials}

The surviving prehistoric materials from Egypt trace out a potted timeline (Table 22.1). Of the early Egyptian Neolithic to the early fifth millennium BC, little is currently known. The destructive force of a once annually flooding and continuously migrating Nile may account for Egypt's lacunae in archaeological features, especially considering the exceptionally low level of the Nile in this time period (Hassan 1988, 142-3). Egypt's earliest known Neolithic burial grounds are three small, densely packed cemeteries, together containing some 39 graves, in the southwestern Saharan Desert at Gebel Ramlah dating to the mid-fifth millennium BC (Kobusiewicz et al. 2004; Kobusiewicz et al. 2009). At the northern end of the country, possibly a little later in the fifth millennium, 'house burials' in what appear to be the abandoned part of settlements are known from el-Omari (Debono \& Mortensen 1990, 67-77) and Merimde Beni-Salame (but see Badawi 1978; Junker 1929, 185-202; Kemp 1968). At these Lower Egyptian sites, the dead were placed in shallow pits with little in the way of material accompaniments, save for the occasional pot. From the mid-to-late fifth millennium BC larger, separate places for the dead were created in northern Upper Egypt, at Badari, Matmar, Mostagedda and Qau (Brunton \& Caton-Thompson 1928), as separate locations away from the living. In an archaeological record where substantial late Neolithic settlement vestiges remain elusive these cemeteries begin to emerge as the primary nodes of social gravity, constituting an 'urbanization of the dead' (Wengrow 2006).

It is in such mid-to-late fifth millennium Upper Egyptian contexts that grave-pits also became something other than simply a container for the body. Over the course of the subsequent fourth millennium BC (the Predynastic) such spaces became the frames for constructing increasingly elaborate material dialogues between objects and subjects (Fig. 22.1) and they provided an arena for the contemplative viewing of the dead by surviving communities. The careful orchestration of such burial space is notable and there existed an affective aesthetic in grave composition (Stevenson 2007; Stevenson 2009a). The attentive furnishing of Predynastic graves in this manner has been the most frequently cited evidence for the emergence of ancient Egyptian beliefs in an afterlife. In so doing, however, the emphasis is necessarily placed upon the manner in which beliefs prefigure practice, but this neither explains their emergence nor their development.

In addition to the rich provisioning of graves, there was also considerable experimentation in body treatments during the Predynastic: post-interment removal of the skull (e.g. Adaima, see MidantReynes et. al. 1996. 96), rearrangement of skeletal parts within the grave (e.g. el-Amrah, see RandallMaclver \& Mace 1902, pl. v; Wengrow 2006, 116-19), and partial mummification in the form of resin-soaked linen pressed upon the hands and around the face of select individuals (e.g. Hierakonpolis, see Jones 2002; 2007). Animal burials within cemeteries are also known (Flores 2003), the most striking of which are within cemetery HK 6 at Hierakonpolis. This latter elite necropolis is composed of large subterranean tombs and was founded at a surprisingly early date, c.3700 BC. With its unique evidence for organic superstructures (see Friedman 2011) HK 6 forms a starkly different funerary arena than is attested for the first rulers of the emergent Egyptian state several centuries later at Abydos (see below) and this serves to underscore the complexity and uncertainly of developmental trajectories. Nevertheless, what remains consistent across this time is the intensity of social engagement with such spaces for the dead and the manner in which early communities along the Nile became increasingly entangled within elaborate funerary displays of a dramatic and stimulating character. These have previously been interpreted with reference to the formation of social memories (e.g. Wengrow 2006, 121-2), but if the creation of social memories is predicated upon an embodied sense of this past (cf. Malafouris, this volume), then these displays 
could be equally construed as moments when a projective 'sense of immortality' as envisioned by Lifton \& Olson (1974) could also be encountered. There is the potential in the future therefore more explicitly to link models of social memory formation with discussions concerning emergent conceptualizations of the afterlife.

\begin{tabular}{|l|l|l|}
\hline Period & Description & cal. BC \\
\hline Badarian & Late Neolithic & ca. $4350400-34750000$ \\
\hline Naqada IA-IIB & Early Predynastic (Amratian) & $\begin{array}{l}\text { ca. } 4000 / 3900- \\
36003750(?)-3450\end{array}$ \\
\hline Naqada IIC-IID2 & Middle Predynastic (Gerzean) & ca. 3450600-335250 \\
\hline Naqada IIIA1-IIIB & Late Predynastic & ca. 3325-308550-3150 \\
\hline Naqada IIIC1-D & First Dynasty/Early Dynastic Period & ca. 3085150-2867686 \\
\hline
\end{tabular}

table 11.1 .7$)$.

\section{Persistent places}

As noted above Predynastic cemeteries were particularly meaningful nodes of social gravity. This can be further highlighted with reference to survey work around the area of Abydos, which has mapped the location of cemeteries in the landscape. The pattern of Predynastic sites in this region (Patch 1991) demonstrated that if the low desert near a settlement site was not well formed, communities would select suitable areas further from their residences to act as dedicated spaces for their dead, although it was preferable to find one as close to the living areas as possible (Patch 2004, 907-11). The burial areas themselves rarely extend more than $100 \mathrm{~m}$ into the low desert and are concentrated at the desert edge, ideally with ease of access from a small wadi connected to the floodplain. Such promontories provided a panoramic view of the Nile valley, granting a vantage point that would have underscored for at least some of the funeral participants their sense of separation from the habitual boundaries of mundane life along the Nile's banks and thereby conceivably contributing to a sense of experiential immortality. The physical distancing of the living from the dead in this manner plausibly generated new cosmologies of landscape and, in turn, new ways of relating to the dead. For the living, a physical journey away from habitation zones to the desert necropolis now featured as an aspect of funerary proceedings, further providing an embodied sensation of separation and locatedness. This may not just have presaged later dynastic Egyptian conceptions of a 'land of the dead' as the concept may itself have been born out of the experience of generations of practice.

Over the course of the Predynastic period some of these cemeteries developed into particularly large necropoleis as generation after generation returned over the centuries with the bodies of their dead. At Naqada, for example, Flinders Petrie and his team excavated some 2000 graves (Petrie \& Quibell 1896), while at Abydos more than 700 tombs (Fig. 22.2) dating across the entire fourth millennium have been explored in the Umm el-Qa'ab (Hartman 2011, 918). Excavators' plans of these sites visualize these landscapes (Fig. 22.2) as pockmarked with grave pits that rarely intersect, betraying the existence of above-ground structures that must once have demarcated these plots, but which are now long gone. Whatever form these monuments took-conceivably simply a low mound (see Crubézy et al. 2002, 454) -these would have acted as material 'citations' (Jones 2005, 199-200) for past practices that would have constrained and enabled the arrangement of further burials (Mizoguchi 1993, 225). The result is that at several sites circular patterning in the placement of interments can be discerned (Stevenson 2009b, 182-3), such as at Mostagedda where the excavator (Brunton 1937, 42) conjectured that tombs may have been arranged around a hearth, at Naga-ed-Dêr where kinship groups have been inferred (Savage 1997), and at HK43, Hierakonpolis, it was suggested that grave plots may have surrounded an above-ground monument (Friedman et al. $1999,4)$. Such physical demarcations of past lives permitted these areas to accrue a visible and 
tangible temporal depth. For the mourners this was the stage for contemplative reflection of not just the recently deceased, but of individuals who no longer had anyone in the surviving community who had ever known them personally (cf. Kuijt 2008; Wason 2010). In this manner a new kind of dead could have emerged whose presence may have aroused some sense of the longue durée as personal remembrances of specific individuals began to blend with the social memory of forgotten persons. This possibly permitted an awareness of community that transcended the generations (Cannon 2002, 194), and thereby a sense of experiential transcendence and a 'continuous present'. The landscape context of these sites, therefore, might not only have been predicated upon certain beliefs, but also actively shaped these through emotional and embodied experience (Williams 1999, 58).

It would be tempting to take these observations of Egyptian cemetery micro-traditions (Chapman 2000) a step further and infer from the patterns in the spread of grave structures continuous lineages of ancestors upon which positions in living society could be negotiated, eventually leading to the emergence of Egypt's first rulers. Such explanations based upon ancestor veneration have for the last decade or so remained prevalent in many narratives of later prehistory, despite critique (Whitley 2002). They have also been invoked as the basis upon which Egyptian religious systems could have been constructed through the elevation of certain ancestors or rulers to divine status (e.g. Edwards 2005, 124). To do so, however, is to ignore the discontinuities in the archaeological record and it is these that are most revealing. These suggest that while encountering ancestors probably did have a role in the creation of place and in the conceptualization of continued existence beyond death, they alone are an insufficient basis for identifying the origins of an 'immortal kingship' (cf. Hocart 1954; Metcalfe \& Huntingdon 1979, 153). The unique elite cemetery of the First Dynasty kings at Abydos can serve as a case study to explore these discontinuities and investigate negotiations of mortuary setting and practice.

\section{Abydos: re-orientating collective experiences of time and space}

Later third millennium BC (Old Kingdom) representations of the afterlife make it clear that different forms of the hereafter were envisioned for the king, as a divinity on earth, in comparison to the rest of society. Non-royal tombs, for example, were where the dead could continue to exist in a hereafter, for which food and other material offerings were required for survival (Baines 1995, 138; see also Wengrow 2006, 266-7). Old Kingdom royal mortuary architecture on the other hand sought to ensure the king's ascension to the world of the gods (Assmann 2001, 369). This gulf between king and commoner was clearly evinced at the outset of the First Dynasty in the mortuary realm, but these "dynastic constructions of death were not simply a 'logical' extension or refinement of Predynastic ones" (Wengrow 2006, 226). This schism in the developmental trajectory of Egyptian mortuary practice was arguably necessary in order to achieve a shift in the ontological status of certain deceased royal individuals. The manner in which this was accomplished, I suggest, seems to have been-at least partially - through a dramatic reorientation of the collective experience of time and space, which was orchestrated by elite communities who sought to establish a new sense of order and, by extension, an emergent sense of alternative immortalities.

This reorientation was played out at the end of fourth millennium BC in the desert beyond Abydos's alluvium, where the first rulers of the formative Egyptian state chose to construct their ceremonial heart, in the area known today as the Umm el-Qa'ab. Set against the arresting backdrop of white limestone cliffs, the Umm el-Qa'ab contains an expansive Predynastic cemetery, the graves of which extend across almost the entirety of the fourth millennium. By at least Naqada IIC this burial ground had become the exclusive preserve of elite members of society, whose social abilities allowed for the presencing in their graves of a wide range of local and exotic materials, as well as specialist craft products. Closer to the Nile, cemeteries composed of smaller tombs, with more humble and

Commented [MJB2]: Do you just mean 'presence' here?

Commented [AES3]: Nope -1 definitely meaning 'presencing' I can put a citation or endnote here to e.g. Ray (1987)'Material metaphor, social interaction and historical reconstructions: metaphor, social interaction and historical reconstructions:
exploring patterns of association and symbolism in the Igbo-Ukwu exploring patterns of association and symbolism in the Igbo-Ukw.
corpus' in Hodder, I. (ed.) Archaeology of Contextual Meanings. corpus' in Hodder, I. (ed.) Archaeology of Contextual Meanings. 'involves the use of material symbols to denote individuals or categories of person in contexts from which they are remote' (p.66) There are plenty more uses of the term in archaeological texts. 
restricted grave furniture were constructed (Stevenson 2009c). By the Naqada IIIA/B period the graves of Cemetery $U$ had become even larger, multi-chambered structures that framed the material performances of elite culture. Included in their number is tomb U-j (Dreyer 2011), the largest and most richly endowed tomb of the so-called 'Dynasty 0 ' rulers, notable also for several hundred small ivory and bone tags bearing the earliest currently-known hieroglyphs in Egypt. Although unique in many respects, this tomb was still physically situated in relation to the older graves around it. The primary arena for encountering a sense of immortality in Cemetery $\mathrm{U}$, throughout the Predynastic period, was in this setting, both visibly and experientially inter-generational, with the juxtaposition of successive interments materially citing ancestral ties and status. Such commemorative practice is underscored by the presence of an offering area to the south of tomb U-j where more than a hundred small clay dishes, offering plates and vessels were recovered. Several of these date to a century after tomb U-j was constructed, with some bearing the name of king Narmer, attesting to cult activity at this spot over several generations.

A short distance to the south of Cemetery $U$, the rulers of what became Egypt's First Dynasty chose to be buried in a cemetery constituted by tombs of a very different character. Although a continuation of Cemetery $U$, the royal burials of Cemetery B materialized a very different set of social relationships and they completely re-orientated the dominant temporal frame of reference. From the time of King Aha, rather than a singular burial being set directly within the wider landscape of its forebears, each ruler's tomb lay within its own complex of carefully choreographed subsidiary burials especially created to accompany the ruler to the grave. The nature of the deaths of those placed here is far from clear, although human sacrifice has become the more commonly cited cause. Certainly the fact that from the reign of Djer subsidiary graves were created as contiguous rows, with each chamber sharing a wall with another, makes it seem unlikely that each was roofed individually, and thus king and company were probably laid out in these spaces in one massive funeral. If previous Predynastic cemeteries can be seen to have contained 'two types of dead' (cf. Boyd, this volume) - the recently deceased and ancestors-in the Umm el-Qa'ab another category of dead emerged, one that was created specifically for the occasion of the ruler's funeral.

The first of these tomb complexes, that of Aha, is unique. It comprises three discrete, large, mudbrick-lined subterranean chambers, in linear alignment with two medium-sized chambers, beyond which lie 11 rows of three individual chambers, each holding the body of a young male (20-30 years of age). Finally, laid in an elongated pit at the rear, were the bodies of seven juvenile lions. The uniform demography of the human remains argues against these men having died naturally (Dreyer 1990, 67, 81-6). The complex of Aha's successor, Djer, is several orders of magnitude larger, with a central burial chamber encircled by 318 subsidiary burials (Fig. 22.3). The whole complex extends across some 2800 square meters. The placement of these retainer tombs was carefully choreographed so that the largest were next to the King's burial chamber, with progressively smaller chambers placed further away. The funerary entourage of the next ruler, Djet, had also been attentively orchestrated, with each retainer's name painted in red ink on the southern end of his or her chamber. Above ground, crude limestone stelae, with names and titles roughly executed upon them were also erected to mark the resting place of these individuals (Martin 2011; Fig. 22.4). Inscribed on the landscape around the king was therefore a very rigid topography of social structure. Within both Djer and Djet's complexes there is a break in the rows of burials in the southwest corner. These align with the great cleft in the limestone cliffs beyond, often interpreted as a sacred passageway to a realm beyond (e.g. Richards 1999, 92), forming another possible example of the landscape's role in providing a focus for experiential transcendence.

The practice of retainer sacrifice diminished in scale in ruler's funerals subsequent to that of king Djer, but nevertheless, by the end of the First Dynasty the demise of eight rulers had still resulted in deaths of at least 900 people (Engel 2008). And this was just in the Umm el-Qa'ab. Closer to the 
Abydene alluvium, the associated royal mortuary enclosures of the First Dynasty monarchs were similarly framed by subsidiary burials (Petrie 1925): around 511 are currently known. ${ }^{3}$ Elsewhere in the country the top echelons of First Dynasty society also drew towards them the death of othersat Saqqara, Giza and Abu Roash. In total, over the period of only a century, nearly 2000 people met their end with the deaths of specific individuals.

Following the lead of Susan Kus (1992), Ellen Morris (2007) has explored the sensuous and stimulating spectacle that probably accompanied these large-scale funerals-the awe-inspiring sights, sounds and smells that would have saturated the atmosphere of the Umm el-Qa'ab some 5000 years ago as each corpse was interred around their ruler, together with hundreds of thousands of material offerings. So massive was the scale of these proceedings that sensuous traces still haunted the Umm el-Qa'ab in the twentieth century AD when the site's most prominent excavator, W.M.F.Flinders Petrie, explored the area. As Petrie cut through the fill of the burial of Semerkhet he was struck by a 'scent that was so strong' as the tomb was 'filled to three feet deep with sand saturated with ointment' (Petrie 1900, 14). As Morris $(2007,17)$ has observed, later religious writings describe how the presence of a god was perceived first through experiencing a divine scent. In this manner, sensual experience could render the imperceptible perceptible, providing a trigger for sensing the continued presence of deceased individuals.

The profoundly stimulating and dramatic character of these spectacles brought the body politic into forceful confrontation with the death of the body natural and in so doing the body politic itself was thrust into the immediate perceptual field of surviving communities. Crucially, the effectiveness of these rituals was enhanced by the way in which they focused emotional attention not just upon the spectacle of a ruler's death. They also centred that attention upon the loss of several hundred other named, individualized human lives, all of whom seemed to have held very specific roles and so whose demise must therefore have left gaps in the social fabric of Early Dynastic society. Thus, the passing of a single specific person conceivably reverberated with emotional intensity in the lives of several hundred families, thereby potentially affecting thousands of other people (contra Baines 1995,137 ). Regardless then of the visibility of the actual funerals themselves (and questions remain as to the audience in the Umm el Qa'ab itself) the sovereign's death still had the potential to draw in an enormous web of social relations. The generation of a sense of immortality here truly was 'othercentred' rather than 'self-centred'. In contrast to the ritual arena of Cemetery $U$, the contemplative viewing of ancestors and the experience of temporal depth in Cemetery B seem to be arguably less important than the moment brought about by orchestrating the death of large numbers of individuals who had all held particular social status in life. Rather than these ceremonies contributing then to a sense of a 'continuous present' - a present that contained both the ancient past and distant future-the sense being evoked might be better characterized as one that made a very particular present continuous. This example of poesis, I would suggest, brought into being a very different sense of the immortality of the ruler in comparison to the many, because the extension of social relations beyond the death of several hundred beings was inextricably entangled with the death of one single person. How this royal person was buried relative to everyone else was not simply a symbolic performance of kingship. Instead it actively accomplished a visceral sense of the transformation of social order. In the chaos caused by the death of both one and many, rupturing the flow of social life, order could be enacted, mapped out and experienced.

\section{Conclusion}

The indefatigable Flinders Petrie excavated thousands of ancient Egyptian tombs in his long career. In synthesizing what such funerary evidence might mean for Egyptian conceptions of the hereafter he concluded that there 'was no possible question to his [the Egyptian's] mind as to the fact of immortality, however varied and contradictory might be his beliefs about the conditions of it' (Petrie 
1924, 3). In seeking to account for the ancient Egyptians' commitment to mortuary provision simply appealing to the minds of ancient peoples in this manner is no longer interpretively satisfactory. If, however, a sense of immortality is predicated upon the intuitive sense of the continued existence of others then it is the embodied engagement with the material manifestations of the dead that may be one of the ways in which experiential immortality could have been engendered and developed. This further supports Hertz's conviction that the treatment of the body can allow insight into beliefs concerning the nature of the soul, although as archaeologists we can take this further if we consider burial spaces as form of 'extended skin' (Wengrow 2006, 166). By examining archaeologically the staging of burial rites, how the dead were incorporated into the landscape and related spatially both to each other and to surviving communities, it may be possible to begin to model the changing stimuli for ancient responses. In particular, the stimulating and dramatic character of First Dynasty royal mortuary practices provided concrete referents that allowed such ceremonies to have a coercive power and a claim to represent another reality in which one person's afterlife could become conceptually different. Rather than immanent, these rituals were conspicuously material and it is this that provides the basis for archaeologists to tackle the nature of the immaterial. Ultimately, the affective intertwining of emotion, politics and religion that characterized the early Egyptian state is likely to have been one of the major factors that contributed to the centrality of the mortuary cult in ancient Egyptian society not just at its inception, but for the millennia to come.

\section{Captions}

Figure 22.1. A Naqada IIC burial from Mahasna containing a body encircled by pottery (courtesy of the Egypt Exploration Society).

Figure 22.2. Map of Cemeteries B and U, Umm el-Qa'ab, Abydos (courtesy of the DAl, OrientAbteilung, Berlin).

Figure 22.3. Map of the tombs of the First and Second-Dynasty rulers at Abydos (courtesy of the DAI, Orient-Abteilung, Berlin).

Figure 22.4. An above-ground funerary stela from around the tomb of Den (courtesy of the Egypt Exploration Society).

\section{References}

Anderson, B., 1983. Imagined Communities. Reflections on the Origin and Spread of Nationalism. London and New York, NY: Verso.

Assmann, J., 2001. Death and Salvation in Ancient Egypt. New York, NY: Cornell University Press.

Badawi, F.A., 1978. Die Grabung der ägyptischen Altertümerverwaltung in Merimde-Benisalâme im Oktober/November 1976. Mitteilungen des Deutschen Archäologischen Instituts, Abteilung Kairo 34, 43-51.

Baines, J., 1995. Origins of Egyptian kingship, in Ancient Egyptian Kingship, ed. D. O'Connor \& D.P. Silverman. Leiden: Brill, 95-156.

Barrett, J., 1994. Fragments from Antiquity. An Archaeology of Social Life in Britain 2900-1200 BC. Oxford: Blackwell.

Bell, C., 1997. Ritual. Perspectives and Dimensions. Oxford: Oxford University Press. 
Bering, J.M., 2002. Intuitive conceptions of dead agents' minds: the natural foundations of afterlife beliefs as phenomenological boundary. Journal of Cognition and Culture 2, 263-308.

Bering, J.M., 2006. The folk psychology of souls. Behavioral and Brain Sciences 29, 1-46.

Bering, J.M., 2008. The end? Why so many of us think our minds continue after we die. Scientific American Mind 19, 34-41.

Bloch, M., 2008. Why religion is nothing special but is central. Philosophical Transactions of the Royal Society B: Biological Sciences 363(1499), 2055-61.

Boivin, N., 2009. Grasping the elusive and unknowable: material culture and ritual practice. Material Religion 5(3), 266-87.

Brunton, G., 1937. Mostagedda and the Tasian Culture. London: Bernard Quaritch.

Brunton, G. \& G. Caton-Thompson, 1928. The Badarian Civilisation and Prehistoric Remains near Badari. London: Bernard Quaritch.

Cannon, A., 2002. Spatial narratives of death, memory and transcendence, in The Space and Place of Death, ed. L. Aragon, H. Silverman \& D. Small. Arlington, TX: American Anthropological Association, 191-9.

Carr, C., 1995. Mortuary practices: their social, philosophical-religious, circumstantial, and physical determinants. Journal of Archaeological Method and Theory 2(2), 105-200.

Chapman, J., 2000. Tension at Funerals. Micro-tradition Analysis in Later Hungarian Prehistory. Budapest: Archaeolingua publications.

Crubézy, E., J. Thierr \& B. Midant-Reynes, 2002. Adaïma, Vol. 2. La nécropole prédynastique (Fouilles de I'Institut français d'archéologie orientale 47). Cairo: Institut français d'archéologie orientale.

Davies, D., 2000. Robert Hertz: the social triumph over death. Mortality 5(1), 97-102.

Debono, F. \& B. Mortensen, 1990. El Omari. A Neolithic Settlement and Other Sites in the Vicinity of Wadi Hof, Helwan (Deutsches Archäologisches Institut. Abteilung Kairo 82). Mainz am Rhein: Phillip von Zabern.

Dee, M., D. Wengrow, A. Shortland, A. Stevenson, F. Brock, L. Flink \& C. Bronk Ramsey, 2013. An absolute chronology for Early Egypt using radiocarbon dating and Bayesian statistical modelling. Proceeding of the Royal Society A 469 (215), doi: 10.1098/rspa.2013.0395

DeMarrais, E., 2011. Figuring the group. Cambridge Archaeological Journal 21(2), 165-86.

Dreyer, G., 1990. Umm el-Qaab: Nachuntersuchunen im frühzeitlichen Königsfriedhof 3./4. Mitteilungen des Deutschen Archäologischen Instituts, Abteilung Kairo 46, 18-27.

Dreyer, G., 2011. Tomb U-j: a royal burial of Dynasty 0 at Abydos, in Before the Pyramids. The Origins of Egyptian Civilization, ed. E. Teeter. Chicago, IL: Oriental Institute, 131-8. 
Edwards, D.N., 2005. The archaeology of religion, in The Archaeology of Identity. Approaches to Gender, Age, Status, Ethnicity and Religion, ed. M. Diaz-Andreu, S. Lucy, S. Babić \& D.N. Edwards. London: Routledge, 110-28.

Engel, E.-M., 2008. The royal tombs at Umm el-Qa'ab. Archéo-Nil 18, 30-41.

Flores, D.V., 2003. Funerary Sacrifice of Animals in the Egyptian Predynastic Period. Oxford: Archaeopress.

Friedman, R.F., 2011. Hierakonpolis, in Before the Pyramids The Origins of Egyptian Civilization, ed.. Chicago, IL: Oriental Institute, 33-44.

Friedman, R.F., A. Maish, A.G. Fahmy, J.C. Darnell \& D. Johnson, 1999. Preliminary report on Field Work at Hierakonpolis: 1996-1998. Journal of the American Research Center in Egypt 36, 1-35.

Hartmann, R., 2011. The chronology of Naqada I tombs in the Predynastic cemetery U at Abydos, in Egypt at its Origins 3 (Orientalia Lovaniensia Analecta 205), ed. R.F. Friedman \& P. Fiske.. Leuven: Peeters Publishers, 918-38.

Hassan, F., 1988. The Predynastic of Egypt. Journal of World Prehistory 2(2), 135-78.

Hendrickx, S., 2006. Predynastic-Early Dynastic chronology, in Ancient Egyptian Chronology, ed. E. Hornung, R. Krauss \& D. Warburton. Leiden and Boston: Brill, 55-93.

Hertz, R., 1960. A Contribution to the Study of the Collective Representation of Death, in Death and the Right Hand, by R. Hertz, trans. R. Needham \& C. Needham. New York, NY: The Free Press.

Hodder, I., 2010. Conclusions and evaluations, in Religion in the Emergence of Civilization. Catalhoyuk as a Case Study, ed. I. Hodder. Cambridge: Cambridge University Press, 332-55.

Hocart, A.M., 1954. Social Origins. London: Watts.

Hodge, K.M., 2011a. Why immortality alone will not get me to the afterlife. Philosophical Psychology 24(3), 395-410.

Hodge, K.M., 2011b. On imagining the afterlife. Journal of Cognition and Culture 11, 367-89.

Jones, A., 2005. Lives in fragments? Personhood and the European Neolithic. Journal of Social Archaeology 5(2), 193-224.

Jones, J., 2002. Funerary textiles of the rich and poor. Nekhen News 14, 13.

Jones, J., 2007. New perspectives on the development of mummification and funerary practices during the pre- and Early Dynastic periods, in Proceedings of the Ninth International Congress of Egyptologists. Vol. I, ed. J.-C. Goyon \& C. Cardin. Leuven: Peeters Publishers, 979-89.

Junker, H., 1929. Vorläufiger Berichtüberdie Grabungder Akademieder Wissenschaftenin Wien auf der neolithischen Siedelung Merimde-Benisalâme (Westdelta) vom 1. bis 30. März 1929. Wien: Akademie der Wissenschaften.

Kemp, B., 1968. Merimda and the theory of house burial in Prehistoric Egypt. Chronique d'Égypte. Bulletin périodique de la Fondation Égyptologique Reine Élisabeth 43, 22-3.

Kertzer, D.I., 1988. Ritual, Politics and Power. New Haven, CT: Yale University Press. 
Kobusiewicz, M., J. Kabaciński, R. Schild, J. Irish \& F. Wendorf, 2004. Discovery of the first Neolithic cemetery in Egypt's western desert. Antiquity 78, 566-78.

Kobusiewicz, M., J. Kabaciński, R. Schild, J. Irish \& F. Wendorf, 2009. Burial practices of the final Neolithic pastoralists at Gebel Ramlah, Western Desert of Egypt. British Museum Studies in Ancient Egypt and Sudan 13, 147-74.

Kuijt, I., 2008. The regeneration of life: Neolithic structures of symbolic remembering and forgetting. Current Anthropology 49(2), 171-97.

Kus, S., 1992. Toward an archaeology of body and soul, in Representations in Archaeology, ed. J.C. Gardin \& C.S. Peebles. Bloomington, IN: Indiana University Press, 168-77.

Laneri, N. (ed.), 2007. Performing Death. Social Analyses of Funerary Traditions in the Ancient Near East and Mediterranean. Chicago, IL: Oriental Institute.

Lifton, R.J. \& E. Olson. 1974. Living and Dying. London: Wildwood House.

Martin, G., 2011. Private Stelae of the Early Dynastic Period from the Royal Cemetery at Abydos. Wiesbaden: Harrassowitz.

Mauss, M., 1967. The Gift, trans. I. Cunnison. New York, NY: Norton and Co.

Metcalf, P. \& R. Huntingdon, 1979. Celebrations of Death. The Anthropology of Mortuary Ritual. Cambridge: Cambridge University Press.

Midant-Reynes, B., N. Buchez, E. Crubézy \& T. Janin. 1996. The Predynastic site of Adaima: settlement and cemetery, in Aspects of Early Egypt, ed. A.J. Spencer. London: British Museum, 93-7.

Mizoguchi, K., 1993. Time in the reproduction of mortuary practices. World Archaeology 25(2), 22335.

Morris, E., 2007. Sacrifice for the state: First Dynasty royal funerals and the rites at Macramallah's rectangle, in Performing Death. Social Analyses of Funerary Traditions in the Ancient Near East and Mediterranean, ed. N. Laneri. Chicago, IL: The Oriental Institute, 15-37.

Patch, D.C., 1991. The Origin and Development of Urbanism in Egypt. A Regional Survey. Unpublished PhD Dissertation, University of Pennsylvania.

Patch, D.C., 2004. Settlement patterns and cultural change in the Predynastic Period, in Egypt at its Origins. Studies in Memory of Barbara Adams (Orientalia Lovaniensia Analecta 138), ed. S. Hendrickx, R.F. Friedman, K.M. Cialowicz \& M. Chlodnicki. Leuven: Peeters Publishers, 905-18.

Pearson, M., 1998. Performance as valuation: early Bronze Age burial as theatrical complexity, in The Archaeology of Value, Essays on Prestige and Processes of Valuation, ed. D. Bailey. Oxford: Archaeopress, 32-41.

Petrie, W.M.F., 1900. The Royal Tombs of the First Dynasty. London: Egypt Exploration Fund.

Petrie, W.M.F., 1924. Immortality, in Immortality, ed. J. Marchant. London: Putnam, 3-18. 
Petrie, W.M.F., 1925. Tombs of the Courtiers. London: British School of Archaeology in Egypt.

Petrie, W.M.F. \& J. Quibell, 1896. Naqada and Ballas. London: British School of Archaeology in Egypt.

Price, N., 2008. Bodylore and the archaeology of embedded religion: dramatic license in the funerals of the Vikings, in Belief in the Past. Theoretical Approaches to the Archaeology of Religion, ed. D. Whitley \& K. Hays-Gilpin. Walnut Creek, CA: Left Coast Press, 143-66.

Randall-Maclver, D. \& A. Mace, 1901. El-Amrah and Abydos. London: Egypt Exploration Fund.

Rappaport, R.A., 1999. Ritual and Religion in the Making of Humanity. Cambridge: Cambridge University Press.

Richards, J., 1999. Conceptual landscapes in the Egyptian Nile Valley, in Archaeologies of Landscape. Contemporary perspectives, 83-100. Oxford: Blackwell.

Savage, S., 1997. Descent group competition and economic strategies in Predynastic Egypt. Journal of Anthropological Archaeology 16, 226-68.

Seremetakis, N., 1991. The memory of the senses. Part I: marks of the transitory, in The Senses Still. Perception and Memory as Material Culture in Modernity, ed. N. Seremetakis. Chicago, IL and London: University of Chicago Press, 1-18.

Stevenson, A., 2007. The aesthetics of Predynastic Egyptian burial: Funerary performances in the fourth millennium BC. Archaeological Review from Cambridge 22(1), 76-92.

Stevenson, A., 2009a. Predynastic burials, in UCLA Encyclopaedia of Egyptology, ed. W. Wendrich. http://escholarship.org/uc/item/2m3463b2 (accessed 20 March 2014).

Stevenson, A., 2009b. Social relationships in Predynastic burials. Journal of Egyptian Archaeology 95, 175-92.

Stevenson, A., 2009c. The Predynastic cemeteries of Abydos. Egyptian Archaeology 34, 25-6.

Tarlow, S., 2000. Emotion in archaeology. Current Anthropology 41(5), 713-46.

Thomas, J., 1999. Understanding the Neolithic. London: Routledge.

Venbrux, E., 2007. Robert Hertz's seminal essay and mortuary rites in the Pacific region. Journal de la Société des Océanistes 124, 5-10.

Wason, P.K., 2010. The Neolithic cosmos of Çatalhöyük, in Religion in the Emergence of Civilization. Çatalhöyük as a Case Study, ed. I. Hodder. Cambridge: Cambridge University Press, 268-99.

Wengrow, D., 2006. The Archaeology of Early Egypt. Social Transformations in North-East Africa, 10,000 to 2650 BC. Cambridge: Cambridge University Press.

Williams, H., 1999. Placing the dead: investigating the location of wealthy barrow burials in seventh century England, in Grave matters. Eight studies of first millennium AD Burials in Crimea, England and Southern Scandinavia, ed. M. Rundkvist. Oxford: British Archaeological Reports, 57-86. 
Whitley, J., 2002. Too many ancestors. Antiquity 76, 110-26.

${ }^{1}$ Jan Assmann $(2001,369)$ has made a distinction for ancient Egyptian beliefs between 'continuance' and 'immortality', with the former focused on surviving death in this world and somehow continuing to exist, and the latter as referring to the next world, access to which was the privilege of the gods and the king. I am using the term 'immortality' here in a generic sense to refer broadly to conceptions of human existence after death.

${ }^{2}$ For an overview of Predynastic burial practices see Stevenson 2009a.

${ }^{3}$ Only the enclosures of the first four rulers have so far been confirmed, those of Aha, Djer, Djet and Merneith. 